STAATSRECHT:

Indonesian Constitutional Law Journal Volume 4 Nomor 1 (2020). P-ISSN: 2549-0915. E-ISSN: 2549-0923

\title{
PERUBAHAN KONSTITUSI MELALUI PERJANJIAN INTERNASIONAL DAN DAMPAKNYA TERHADAP KEDAULATAN NEGARA
}

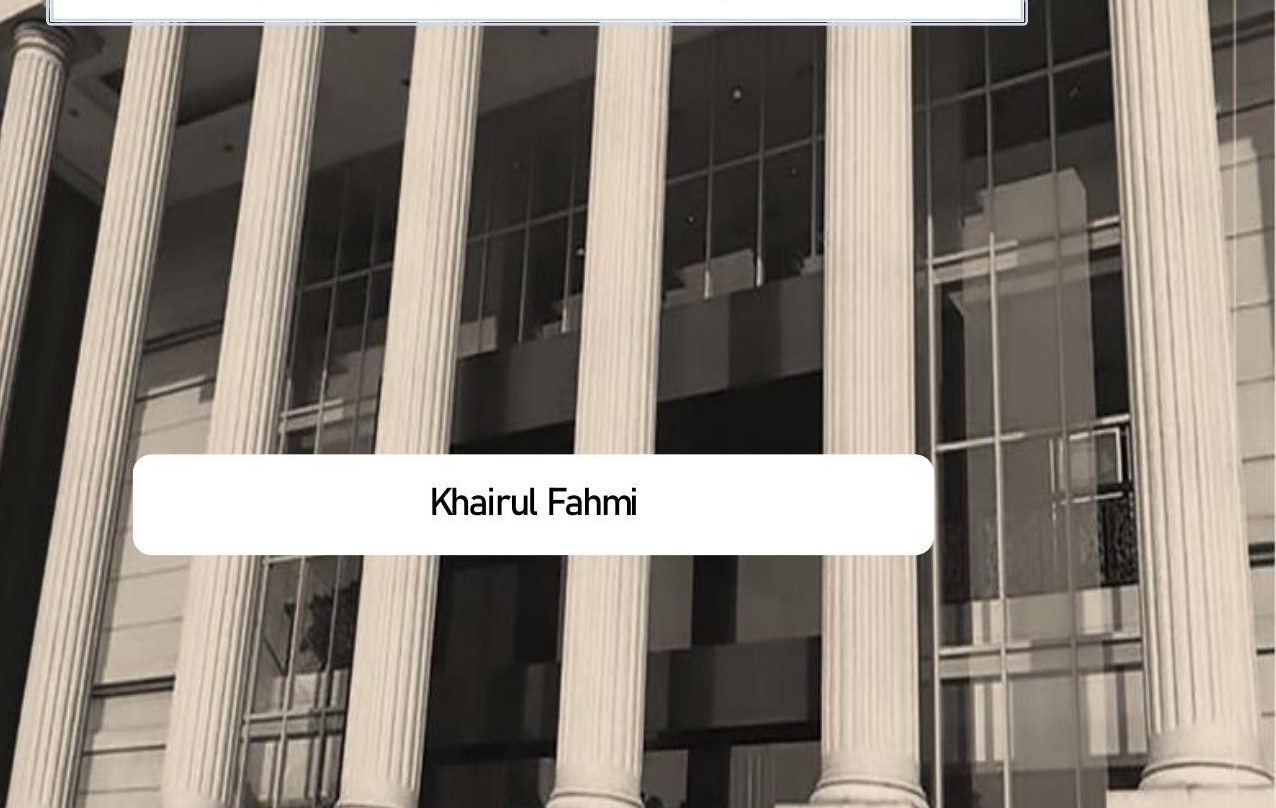




\title{
PERUBAHAN KONSTITUSI MELALUI PERJANJIAN INTERNASIONAL DAN DAMPAKNYA TERHADAP KEDAULATAN NEGARA*
}

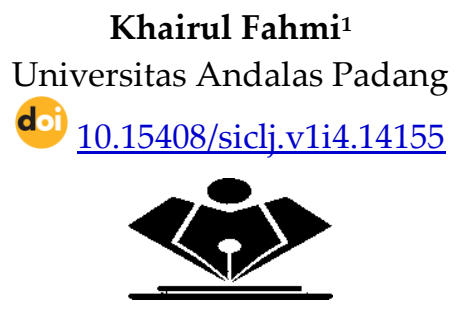

\begin{abstract}
The development of the association of modern states increasingly influences how the constitutional norms of the country are guarded and maintained. Inter-state relations in the economic, social, political, and security sectors established through various treaties have influenced the existence of the constitution because of the impact on multiple changes. Furthermore, it also affects the integrity of the country's sovereignty, especially when there is a conflict between the international legal system and the constitution. In this connection, the problem discussed is how constitutional changes occur through international treaties and how the impact of constitutional changes through international conventions on the existence of state sovereignty placed in the hands of the people. This study concludes, Firstly, the 1945 Constitution as a constitution has not only changed through formal changes in accordance with Article 37 of the 1945 Constitution but has also been changed in an informal manner through the ratification of international treaties. Second, amending the constitution through international treaties can reduce the existence of the constitution as the embodiment of the country's supreme power, which is placed by the people.

Keywords: Changes to The Constitution, International Treaties, Sovereignty
\end{abstract}

* Diterima tanggal 18 Januari 2020, direview tanggal 13 Maret 2020, Publish tanggal 16 Juni 2020.

${ }_{1}$ Dosen Hukum Tata Negara Fakultas Hukum Universitas Andalas Padang. E-mail: khairulfahmi@law.unand.ac.id 


\section{A. PENDAHULUAN}

Sekalipun tidak termasuk salah satu dari empat syarat konstitutif berdirinya negara menurut Pasal 1 Konvensi Montevideo $1933,{ }^{2}$ sulit disangkal bahwa konstitusi merupakan aspek penting sebuah negara. Konstitusi merupakan unsur pokok dari hukum tata negara suatu negara, ${ }^{3}$ terlepas bagaimanapun bentuknya. Bogdanor V. Finer dan B. Rudder mengemukakan, konstitusi merupakan norma-norma yang mengatur alokasi kekuasaan, fungsi, dan tugas dari berbagai lembaga dan petugas pemerintahan serta mengatur mengenai hubungan antara lembaga dan petugas tersebut dengan masyarakat. ${ }^{4}$

Posisi penting konstitusi di atas juga menunjukkan karakter khusus yang dimilikinya. Salah satunya, konstitusi diberi status yang lebih tinggi, sebagai kenyataan hukum, dari pada peraturan-peraturan hukum yang lain dalam sistem ketatanegaraan. ${ }^{5}$ Selain lebih tinggi, karakter khusus konstitusi juga dapat dilihat dalam proses pembentukan maupun perubahannya. Hal mana, baik pembentukan maupun perubahan konstitusi tidak sama dengan pembentukan dan perubahan undang-undang biasa (ordinary law). Walaupun di beberapa negara seperti Selandia Baru konstitusinya dapat diubah dengan proses yang sama seperti ketika mengubah hukum biasa, ${ }^{6}$ namun di banyak negara lain seperti Amerika

2 Unsur konstitutif berdirinya negara menurut Konvensi Montevideo 1933 adalah: (1) penduduk tetap; (2) wilayah tertentu; (3) pemerintahan; (4) kemampuan untuk melakukan hubungan dengan negara lain, dalam J.G. Starke, Pengantar Hukum Internasional (Edisi Kesepuluh), Sinar Grafika, Jakarta, 2003, h.127.

${ }^{3}$ Moh. Mahfud MD., 2001. Dasar \& Struktur Ketatanegaraan Indonesia (Edisi Revisi), Jakarta: Rineka Cipta, h.71.

${ }^{4}$ Peter Cumper, 1999. Cases and Materials-Constitution and Administrative Law, London: Published by Blackstone Press Limited, h.1, dalam Feri Amsari, 2011. Perubahan UUD 1945, Perubahan Konstitusi Kesatuan Republik Indonesia Melalui Keputusan Mahkamah Konstitusi, Jakarta: Rajawali Pers, h.13.

${ }^{5}$ K.C. Wheare, 1975. Modern Constitutions, New York Toronto: Oxford University Press, h.5.

${ }^{6}$ Ibid., h.5. 
Serikat, Kanada, Australia dan juga Indonesia, pembentukan dan perubahan konstitusi memiliki tingkat yang lebih sulit dibandingkan undang-undang. Tingkat kesulitan dari pembentukan, pengundangan, perubahan itulah yang menurut Hans Kelsen dinilai sebagai pembeda antara hukum konstitusi dengan hukum biasa. ${ }^{7}$

Berbedanya tingkat kesulitan dalam membentuk konstitusi dan undang-undang juga linear dengan validitas keberlakuan keduanya. Validitas undang-undang berasal dari konstitusi, sedangkan validitas konstitusi dikontruksikan berasal dari rakyat. Konstruksi demikian telah menjadi postulat yang diakui negara-negara modern. Irlandia misalnya menilai bahwa validitas hukum konstitusinya diklaim berasal dari Tuhan dan rakyat. $^{8}$ Hal yang sama juga terdapat dalam konstitusi India, di mana dinyatakan bahwa validitas konstitusi berasal dari rakyat. ${ }^{9}$ Demikian juga dengan Amerika Serikat yang menempatkan rakyat sebagai sumber validitas keberlakuan konstitusi mereka. Dalam pembukaan konstitusi Amerika dinyatakan: We the people of the United States, in Order to form a more perfect Union, ..., do ordain and establish this Constitution for the United States of America. ${ }^{10}$

Ihwal validitas norma konstitusi serta bagaimana konstitusi tersebut dapat diubah sebagaimana dijelaskan di atas hanyalah dalam lingkup negara tertentu saja, tidak dalam hubungannya dengan negara-negara lain. Dalam arti, pola-pola perubahan konstitusi yang dikenal selama ini belum dilihat dalam perspektif ketika hukum konstitusi tersebut berinteraksi dengan hukum negara lain atau hukum internasional. K.C. Wheare misalnya, sekalipun dalam buku Modern Contitutions juga membahas perubahan konstitusi dalam konteks hubungan antar negara bagian Amerika Serikat, namun dalam hubungan

${ }^{7}$ Hans Kelsen, 1961. General Theory of Law and State, Translated by Anders Wedberg, New York: Russel \& Russel, h.125.

${ }^{8}$ K.C. Wheare, Op.cit., h.53

${ }^{9}$ Ibid., h.54.

10 The United States Constitution. 
antar negara yang saling berdaulat, pola perubahan konstitusi sesungguhnya belum ia singgung.

Sementara perkembangan pergaulan negara-negara modern justru semakin berpengaruh terhadap bagaimana norma-norma konstitusi tetap dijaga dan bagaimana pula ia tetap dapat dipertahankan sebagai wujud kedaulatan masingmasing negara. Sulit dibantah, hubungan antar negara dalam segala aspek seperti ekonomi, sosial, politik dan keamanan akan mempengaruhi eksistensi konstitusi suatu negara. Pada ranah itulah kemudian akan muncul fenomena baru di mana hubungan antar negara yang diwujudkan dalam berbagai perjanjian internasional akan menjadi salah satu penyebab atau bahkan cara sebuah konstitusi negara diubah.

Perubahan konstitusi melalui perjanjian internasional tentu akan berkaitan pula dengan eksistensi kedaulatan negara, di mana sebuah negara berdaulat memiliki kekuasaan tertinggi untuk menentukan hukum yang berlaku dalam negaranya. Jean Bodin mengemukakan, salah satu aspek penting kedaulatan itu adalah kekuasaan untuk membuat hukum sebagai sarana agar kekuasaan dapat dijalankan secara efektif. ${ }^{11}$ Wujud konkrit daulat tertinggi negara ada pada konstitusi.

Dalam konteks itu, masing-masing negara berdaulat memiliki konstitusi dengan basis validitas yang bersumber dari rakyatnya sendiri, bukan rakyat negara lain. Linear dengan itu, proses perubahan konstitusi masing-masing negara juga tunduk pada cara-cara yang ditentukan konstitusi itu sendiri atau menurut cara-cara atau praktik yang diakui oleh rakyat negara tersebut.

Pada kenyataannya, perubahan konstitusi seperti halnya Undang-Undang Dasar Negara Republik Indonesia Tahun 1945 tidak selalu dilakukan dengan mekanisme yang diatur menurut konstitusi. Berbagai langkah legislatif biasa dan juga penafsiran

${ }^{11}$ W. Friedmann, 1953. Legal Theory (Third Edition), London: Stevens \& Sons Limited, h.416. Dalam konteks kekuasaan membuat hukum, Bodin menyamakan antara hukum dengan Undang-Undang. 
konstitusi oleh Mahkamah Konstitusi turut mengubah konstitusi secara informal. Salah satunya, perubahan UUD 1945 melalui pengesahan perjanjian internasional. Ketika sebuah penjanjian internasional yang substansinya berseberangan dengan UUD 1945 tetap disahkan dan diterima menjadi hukum nasional melalui prosedur pembentukan undang-undang biasa, saat itu substansi UUD 1945 sebetulnya telah bergeser dan mengalami perubahan tanpa mengubah teks yang tertera di dalamnya.

Salah satu pengesahan perjanjian internasional yang kemudian berimplikasi terhadap perubahan UUD 1945 adalah ratifikasi Piagam ASEAN atau Charter of the Association of Southeast Asian Nations. Sebagian isi Piagam ASEAN yang disahkan justru telah mengubah substansi UUD 1945, khususnya norma-norma yang terkait dengan penerapan asasasas perekonomian nasional sebagaimana diatur dalam Pasal 33 UUD 1945.

Dalam Pasal 33 ayat (1) UUD 1945 dinyatakan bahwa perekonomian nasional disusun sebagai usaha bersama berdasar asas kekeluargaan. Frasa "perekonomian disusun" dalam ketentuan tersebut bermakna bahwa perekonomian harus disusun, tidak boleh dibiarkan tersusun sendiri melalui mekanisme pasar bebas ala competitive economics. Frasa tersebut juga bermakna bahwa perekonomian diwujudkan dengan berserikat sebagai wujud paham kebersamaan, wujud pengaturan berdasarkan musyawarah dan mufakat dan menolak individualisme atau asas perorangan. ${ }^{12}$

Selain itu, perekonomian berasaskan kekeluargaan adalah perekonomian yang dibangun atas kesadaran budi dan hati nurani manusia untuk mengerjakan segala sesuatu oleh semua orang dan untuk semua di bawah kepemimpinan seseorang atas dasar Pancasila. ${ }^{13}$ Asas ekonomi kekeluargaan sebagaimana

12 Putusan Mahkamah Konstitusi Nomor 33/PUU-IX/2011 terkait Pengujian Undang-Undang Nomor 38 Tahun 2008 tentang Pengesahan Charter of the Association of Southeast Asian Nations (Piagam Perhimpunan BangsaBangsa Asia Tenggara), h.30.

${ }^{13}$ Ibid., h.30. 
diatur dalam Pasal 33 ayat (1) UUD 1945 justru lumpuh akibat kaidah kapitalisme neoliberalisme yang terkandung dalam Pasal 1 ayat (5) dan Pasam 2 ayat (2) Piagam ASEAN. ${ }^{14}$ Secara substansi, dua ketentuan Piagam ASEAN dimaksud menganut prinsip ekonomi liberal, bukan kekeluargaan yang dinyatakan tegas dalam Pasal 33 UUD 1945. Pada gilirannya, pemberlakukan Piagam ASEAN tersebut akan merugikan industri dan perdagangan nasional Indonesia. ${ }^{15}$ Oleh karena Piagam ASEAN diratifikasi dengan Undang-Undang Nomor 38 Tahun 2008 tentang Pengesahan Charter of the Association of Southeast Asian Nations (Piagam Perhimpunan Bangsa-Bangsa Asia Tenggara), Undang-Undang itupun kemudian diuji secara materil melalui Mahkamah Konstitusi.

Hanya saja, dalam putusannya, Mahkamah Konstitusi menyatakan menolak permohonan untuk seluruhnya. ${ }^{16}$ Mahkamah Konstitusi menilai, pelaksanaan Piagam ASEAN masih digantungkan kepada masing-masing negara ASEAN untuk membuat aturannya sebagaimana ditentukan dalam Pasal 5 ayat (2) ASEAN Charter, maka pemerintah Indonesia dalam membuat aturan pelaksanaan tersebut harus sesuai dengan kepentingan nasional berdasarkan UUD $1945 .{ }^{17}$

Dalam pertimbangannya, Mahkamah Kostitusi tidak memberikan pendapat hukum mendalam tentang bagaimana komitmen perekonomian yang diatur Piagam ASEAN yang dinilai bertentangan dengan asas perekonomian nasional dalam Pasal 33 UUD 1945. Selain itu, dari pertimbangan hukum yang disampaikan, justru muncul kesan, Mahkamah menghindar dari memberi penilaian terhadap pertentangan antara asas perekonomian Piagam ASEAN dengan asas perekonomian nasional menurut UUD 1945. Hal itu tergambar dari pendapat MK yang menyatakan isi Piagam ASEAN belum efektif berlaku,

\section{${ }^{14}$ Ibid., h.30 \\ 15 Pengujian UU Ratifikasi Piagam ASEAN Kandas,} http://www.hukumonline.com/berita/baca/l t512cb1408c03e/pengujian-uuratifikasi-piagam-asean-kandas, di akses tanggal 30 Oktober 2015.

${ }_{16}$ Putusan MK Nomor 33/PUU-IX/2011, Op.cit., h.197.

17 Ibid., h.196. 
sehingga ia tidak dapat dikatakan bertentangan dengan UUD 1945. Hal itu sesungguhnya memberi petunjuk bahwa sekalipun MK menolak permohonan, namun sikap itu seakan membenarkan bahwa secara substansi asas perekonomian yang diadopsi Piagam ASEAN bertentangan dengan asas perekonomian nasional. Dengan ditolaknya permohonan tersebut, sebagaimana dinilai banyak kalangan, MK setidaknya telah memperkukuh keberadaan Piagam ASEAN sebagai hukum nasional yang berlaku di Indonesia. ${ }^{18}$

Dengan telah dikukuhkannya Piagam ASEAN menjadi hukum nasional, di mana ketentuan mengenai asas perekonomiannya juga dinilai konstitusional oleh Mahkamah Konstitusi, ketika itu sesungguhnya Pasal 33 ayat (1) UUD 1945 telah diubah. Perubahan tidak terjadi pada teksnya, melainkan pada substansi yang diatur di dalamnya. Fakta inilah kemudian yang dapat dinilai sebagai telah terjadinya perubahan UUD 1945 melalui pengesahan perjanjian internasional.

Berdasarkan uraian di atas, persoalan yang kemudian muncul adalah bagaimana sesungguhnya eksistensi kekuasaan tertinggi yang menjadi dasar validitas konstitusi ketika dihadapkan pada realitas hubungan negara dengan negara lainnya dalam sebuah perjanjian internasional? Apakah kekuasaan tertinggi negara yang berada di tangan rakyat memang tereduksi ketika adanya perjanjian antara negara yang satu dengan negara yang lain? Selanjutnya, bagaimana sesungguhnya perubahan konstitusi melalui perjanjian internasional ini diletakkan dalam teori perubahan konstitusi yang telah dikonstruksi oleh K.C. Wheare?

Sehubungan dengan itu, pertanyaan yang hendak dijawab adalah: Pertama, bagaimana perubahan terhadap Undang-Undang Dasar Negara Republik Indonesia Tahun 1945 dapat terjadi melalui perjanjian internasional yang disahkan oleh Negara Indonesia? Bagaimana keberadaan perjanjian

18 Damos Dumoli Agusman, Arti Penting ASEAN bagi Sistem Hukum Indonesia, http://www.antaranews.com/berita/360866/arti-piagam-asean-bagi-sistemhukum-indonesia, diakses tanggal 31 Oktober 2015. 
internasional dalam konsep tata cara perubahan konstitusi? Apakah perubahan konstitusi melalui perjanjian internasional merupakan bagian dari perubahan konstitusi melalui kebiasaan ketatanegaraan sebagaimana dikemukan K.C. Wheare? Kedua, bagaimana dampak perubahan Undang-Undang Dasar Negara Republik Indonesia Tahun 1945 melalui perjanjian internasional terhadap eksistensi kekuasaan tertinggi negara yang berada di tangan rakyat?

\section{B. METODOLOGI PENELITIAN}

Penelitian ini menggunakan jenis penelitian yuridis normatif. Penulisan yuridis normatif adalah sebuah penelitian secara kepustakaan yang melalui bahan sekunder. ${ }^{19}$ Sumber data sebagai rujukan penelitian ini menggunakan studi kepustakaan. Penelitian ini menggunakan pendekatan perundang-undangan (statue approach), pendekatan konsep (conseptual approach), ${ }^{20}$ dan pendekatan komparatif (comparative approach). ${ }^{21}$

\section{ANALISIS DAN PEMBAHASAN}

\section{Perubahan Konstitusi Melalui Perjanjian Internasional}

K.C. Wheare menyimpulkan, kata "konstitusi" setidaknya digunakan untuk dua pengertian. Pertama, konstitusi merupakan seluruh sistem ketatanegaraan suatu negara, kumpulan berbagai peraturan yang membentuk dan mengatur atau mengarahkan pemerintahan. Sebagian peraturan tersebut bersifat legal dan sebagian lagi bersifat non-legal atau extra-legal

${ }^{19}$ Romy Hanitijo Soemito, 1998, Metodologi Penelitian Hukum dan Jurimetri, Jakarta: Ghalia Indonesia, h.11.

20 Peter Mahmud Marzuki, 2005, Penelitian Hukum, Jakarta: Prenadamedia Group, h.133.

21 Abdulkadir Muhammad, 2004, Hukum dan Penelitian Hukum, Bandung: PT. Citra Aditya Bakti, h.113. 
yang berupa kebiasaan, adat atau konvensi yang mengatur ketatanegaraan. ${ }^{22}$ Definisi itu bersesuaian dengan apa yang sebelumnya pernah ditulis Bolingbroke dalam esainya, On Parties, bahwa konstitusi dipahami sebagai "...that assemblage of laws, institutions and customs, derived from certain fixed principles of reason...that compose the general system, according to which the community hath agreed to be governed". ${ }^{23}$

Sejalan dengan itu, Bagir Manan mengartikan konstitusi sebagai sekelompok ketentuan yang mengatur organisasi negara dan susunan pemerintahan suatu negara. ${ }^{24}$ Konstitusi dalam pengertian itu dibedakan A.V. Dicey menjadi ketentuan konstitusi yang mempunyai sifat hukum dan tidak mempunyai sifat hukum. Pembedaan seperti itu didasarkan pada apakah pengadilan berwenang memaksakan penaatannya dan/atau mengambil tindakan hukum bagi yang tidak taat. ${ }^{25}$

Kedua, konstitusi diartikan sebagai kumpulan peraturan yang biasanya dihimpun dalam satu dokumen atau beberapa dokumen yang berkaitan erat. Dalam arti, konstitusi merupakan hasil seleksi dari peraturan-peraturan hukum yang mengatur pemerintahan negara tersebut dan telah dihimpun dalam sebuah dokumen. ${ }^{26}$ Definisi ini memiliki lingkup yang lebih sempit dibanding pengertian pertama. Berdasarkan definisi yang terakhir ini, tidak tepat mengatakan bahwa negara seperti Inggris mempunyai konstitusi tak tertulis, melainkan lebih cocok dikatakan tidak memiliki konstitusi tertulis. ${ }^{27}$ Walaupun mengkritik pemilahan yang demikian, Wheare sesungguhnya masih memberi ruang adanya klasifikasi antara konstitusi tertulis dan tidak tertulis.

${ }^{22}$ K.C. Wheare, Op.cit., h.1.

${ }^{23}$ Ibid., h.2.

24 Bagir Manan, 1995. Pertumbuhan dan Perkembangan Konstitusi Suatu Negara, Bandung: Mandar Maju, h.5.

${ }^{25}$ A.V. Dicey, An Introduction to Study of the Law of the Constitution, dalam Bagir Manan, Ibid., h.5.

${ }^{26}$ K.C. Wheare, Op.cit., h.2.

27 Ibid. 
Bagir Manan termasuk salah seorang ahli yang berpendapat bahwa dari wujudnya, konstitusi dibedakan antara konstitusi tertulis dan tidak tertulis. Konstitusi tertulis dibedakan lagi antara yang tertulis dalam satu dokumen khusus atau dalam beberapa dokumen yang berkaitan erat satu sama lain. ${ }^{28}$ Salah satu contoh konstitusi tertulis yang tersusun dalam satu dokumen khusus adalah Konstitusi Amerika Serikat, Australia dan juga Indonesia.

Dalam nukilan ini, konstitusi yang dimaksud adalah konstitusi menurut defenisi yang diulas terakhir, yaitu konstitusi tertulis yang dituangkan dalam satu dokumen khusus. Di Indonesia, konstitusi tersebut adalah UUD 1945. Dalam sistem tata urusan peraturan perundang-undangan, UUD 1945 ditempatkan pada kedudukan yang paling tinggi. Sekalipun kedudukan tersebut tidak ditegaskan dalam UUD 1945, namun peraturan perundang-undangan di bawah UUD 1945 seperti Ketetapan MPR Nomor XX/MPRS/1966 menegaskan bahwa UUD 1945 adalah peraturan perundang-undangan dan menempati tata urutan tertinggi atas segala jenis-jenis peraturan perundang-undangan. ${ }^{29}$ Begitu juga Ketetapan MPR Nomor III/MPR/2000 yang di dalamnya ditegaskan bahwa UUD 1945 menempati hirarkhi paling tinggi dalam tata urutan peraturan perundang-undangan. ${ }^{30}$

Pengaturan kedudukan UUD 1945 pada masa-masa setelah itu juga demikian. Terakhir kali adalah Undang-Undang Nomor 11 Tahun 2011 tentang Pembentukan Peraturan Perundang-undangan. Dalam Undang-Undang ini diakui bahwa UUD 1945 merupakan salah satu jenis peraturan perundang-undangan yang secara hirarkhis berada dan membawahkan peraturan perudang-undangan lainnya. ${ }^{31}$

\footnotetext{
${ }^{28}$ Bagir Manan, Op.cit., h.5.

${ }^{29}$ Bagir Manan dan Kuntana Magnar, 1997. Beberapa Masalah Hukum Tata Negara Indonesia, Bandung: Penerbit Alumni, h.106.

${ }^{30}$ Pasal 2 Ketetapan MPR Nomor III/MPR/2000 tentang Sumber Hukum dan tata Urutan Peraturan Perundang-undangan.

${ }^{31}$ Pasal 7 Undang-Undang Nomor 12 Tahun 2011 tentang Pembentukan Peraturan Perundang-undangan.
} 
Terkait jenis dan hirarkhi peraturan perundang-undangan tersebut, Pasal 7 ayat (1) Undang-Undang Nomor 12 Tahun 2011 mengatur sebagai berikut:

Jenis dan hierarki Peraturan Perundang-undangan terdiri atas:

a. Undang-Undang Dasar Negara Republik Indonesia Tahun 1945;

b. Ketetapan Majelis Permusyawaratan Rakyat;

c. Undang-Undang/Peraturan Pemerintah Pengganti UndangUndang;

d. Peraturan Pemerintah;

e. Peraturan Presiden;

f. Peraturan Daerah Provinsi; dan

g. Peraturan Daerah Kabupaten/Kota.

Jenis dan hirarkhi peraturan perundang-undangan di atas sekaligus menunjukan hubungan sekaligus superioritas jenis peraturan yang satu dengan peraturan yang lainnya. Peraturan yang ada pada posisi nomor satu lebih superior di banding nomor dua dan begitu seterusnya sampai ke bawah. Pada saat yang sama, peraturan yang lebih rendah bersumber dari peraturan yang lebih tinggi darinya. Jadi, prinsip kedudukan yang hirarkhis menghendaki agar norma peraturan perundangundangan dapat disusun secara disiplin dan taat asas. Hal mana semuanya berujung pada ketaatan dan kesesuaiannya dengan UUD 1945 sebagai peraturan perundang-undangan sekaligus hukum dasar dengan kedudukan tertinggi dalam tata hukum atau tata uruta peraturan perundang-undangan Indonesia.

Sebagai hukum dasar tertinggi yang diakui sebagai sumber bagi peraturan/hukum yang ada di bawahnya, UUD 1945 dipostulasikan valid karena diterima oleh seluruh rakyat. Dalam arti, keabsahan dan kekuatan berlakunya UUD 1945 adalah karena didukung atau memeroleh legitimasi dari rakyat sebagai pemegang kedaulatan.

Dengan kedudukan paling tinggi karena mendapatkan validitas yang bersumber dari rakyat, UUD 1945 tentunya tidak dapat diubah apalagi dilumpuhkan oleh peraturan perundangundangan yang lebih rendah darinya. UUD 1945 hanya dapat diubah melalui mekanisme yang diatur di dalamnya. Namun 
secara konseptual, ternyata konstitusi tidak selalu berubah menurut tata cara formal yang ditentukan konstitusi itu sendiri, melainkan juga dapat berubah dengan cara-cara lain.

K.C. Wheare mengidentifikasi, konstitusi setidaknya dapat berubah melalui tiga cara, yaitu: perubahan melalui proses amandemen formal, perubahan melalui mekanisme proses keputusan yudisial, dan perubahan melalui kebiasaan dan tradisi hukum konstitusi. ${ }^{32}$ Perubahan konstitusi secara formal ia definisikan sebagai proses perubahan konstitusi yang dilakukan dengan pertimbangan yang matang, memberikan kesempatan kepada rakyat untuk memberikan pendapat, hak minoritas dilindungi dengan menggunakan prosedur tertentu yang diatur masing-masing konstitusi. ${ }^{33}$

Selain diubah melalui mekanisme formal, konstitusi juga dapat berubah melalui penafsiran lembaga yudisial. Dalam mengadili perkara, hakim kadang dihadapkan pada pertentangan antara hukum konstitusi dengan beberapa aturan hukum atau keputusan lain. Dalam kondisi tersebut, hakim dituntut untuk memutuskan apakah yang dimaksud dengan hukum, di mana mereka mesti menentukan tidak hanya arti aturan hukum biasa tetapi juga konstitusi. ${ }^{34}$ Ketika hakim melakukan penafsiran terhadap konstitusi, saat itulah sesungguhnya perubahan konstitusi mungkin terjadi.

Selain perubahan melalui prosedur formal dan penafsiran hakim, Wheare juga mencatat perubahan konstitusi melalui kebiasaan dan tradisi. Kebiasaan dan tradisi yang ia maksud adalah: a binding rule, a rule of behaviour accepted as obligatory by those concerned in the working of the Constitution; by usage is meant no more than a usual practice (aturan yang mengikat, aturan prilaku yang dianggap wajib oleh mereka yang peduli dengan berjalannya konstitusi, yang dimaksud dengan kebiasaan tidak lain adalah praktik yang biasa dilakukan). ${ }^{35}$ Perubahan

\footnotetext{
${ }^{32}$ K.C. Wheare, Op.cit., h.81-82.

${ }^{33} \mathrm{Ibid}$., h.83-84.

${ }^{34}$ Ibid., h.100.

${ }^{35}$ Ibid., h.122.
} 
konstitusi melalui kebiasaan atau tradisi menurutnya bukanlah perubahan yang dilakukan menggunakan mekanisme hukum, melainkan non-hukum yang dinilai memiliki sifat mengikat dan mengatur institusi politik negara.

Tiga cara perubahan konstitusi menurut Wheare di atas sesungguhnya pernah dialami konstitusi Indonesia sepanjang Republik ini berdiri. Bahkan tidak hanya diubah, konstitusi Republik Indonesia bahkan pernah diganti seiring dengan dinamika politik nasional yang terjadi sejak kemerdekaan.

Konstitusi pertama Republik Indonesia adalah UUD 1945 Proklamasi yang disahkan pada tanggal 18 Agustus 1945. Menurut UUD tersebut, sistem pemerintahan yang dianut adalah sistem Presidensial yang tidak murni, atau sistem presidensial semu (kuasi presidensial). ${ }^{36}$ Setelah UUD 1945 resmi ditetapkan sebagai konstitusi negara tanggal 18 Agustus 1945, praktik ketatanegaraan yang terjadi lebih kurang dua bulan setelah itu justru mengubah substansi konstitusi. Hal mana, sistem semi presidensial yang dianut diubah menjadi sistem parlementer. Perubahan dalam praktik tersebut dilakukan tanpa melakukan perubahan terhadap UUD, sehingga terjadi perbedaan antara landasan kostitusional yang ada dengan praktik pelaksanaan pemerintahan saat itu. ${ }^{37}$

Perubahan Konstitusi melalui praktik dalam sejarah ketatanegaraan Indonesia tidak hanya terjadi di masa awal kemerdekaan, melainkan juga terjadi pada masa-masa setelahnya. Berbagai ketetapan MPR diterbitkan dengan materi muatan yang berbeda dari apa yang diatur UUD 1945. MPR pada masa Orde Baru dapat dengan mudah melakukan perubahan konstitusi, baik melalui penafsiran maupun penambahan ketentuan asli. ${ }^{38}$ Salah satunya Ketetapan MPR Nomor IV/MPR/1983 yang pada pokoknya berisi tentang

${ }^{36}$ Mahfud MD., Op.cit., h.92.

${ }^{37}$ Mahfud, Ibid., h.93.

${ }^{38}$ Muhammad Fajrul Falaakh, Komisi Konstitusi dan Peran Rakyat dalam Perubahan UUD 1945, Jurnal Analisis CSIS Tahun XXXI/2002 No. 2, Penerbit Center for Strategic and Internasional Studies, h.194. 
referendum sebagai mekanisme perubahan UUD 1945. ${ }^{39}$ Ketetapan tersebut pada dasarnya telah mengubah substansi Pasal 37 UUD 1945 yang mengatur bahwa perubahan UUD 1945 dilakukan oleh MPR. Ketetapan MPR dimaksud justru mengubah mekanisme perubahan UUD 1945 dari dilakukan oleh MPR menjadi dilaksanakan dengan referendum tanpa mengubah teks Pasal 37 UUD 1945 itu sendiri.

Perubahan UUD 1945 tidak hanya terjadi melalui praktik atau konvensi ketatanegaraan, melainkan juga terjadi secara formal melalui mekanisme yang ditentukan dalam UUD. Dalam Pasal 37 UUD 1945, perubahan harus dilakukan melalui beberapa prosedur yang tidak mudah di MPR. Usulan perubahan mesti diajukan oleh sekurang-kurangnya $1 / 3$ dari anggota MPR, dan perubahannya baru dapat dilakukan jika disetujui oleh sekurang-kurangnya lima puluh persen ditambah satu dari sekurang-kurangnya 2/3 anggota MPR yang hadir dalam Sidang Majelis Permusyawaratan Rakyat. ${ }^{40}$ Perubahan menggunakan mekanisme ini telah dilakukan sebanyak empat kali dalam rentang waktu 1999 hingga 2002.

Selain dua tersebut, UUD 1945 juga pernah diubah melalui penafsiran lembaga peradilan, dalam hal ini Mahkamah Konstitusi. Melalui kewenangan menguji undang-undang terhadap UUD 1945 sebagaimana diatur dalam Pasal 24C ayat (2) UUD 1945, Mahkamah Konstitusi pernah mengubah substansi UUD 1945 tanpa terjadi perubahan teksnya. Dalam perkara Nomor 008/PUU-II/2004 terkait pengujian UndangUndang Nomor 23 Tahun 2003 tentang Pemilihan Umum Presiden dan Wakil Presiden misalnya, Mantan Presiden Abdurrahman Wahid mengajukan pengujian terhadap Pasal 6 huruf (d) Undang-Undang Nomor 23 Tahun 2003 yang menyatakan seorang calon Presiden dan calon Wakil Presiden harus memenuhi syarat: "Mampu secara rohani dan jasmani untuk h.96-96.

${ }^{39}$ Bagir Manan, 2006. Konvensi Ketatanegaraan, Yogyakarta: FH UII Press, ${ }^{40}$ Pasal 37 Undang-Undang Dasar Negara Republik Indonesia. 
melaksanakan tugas dan kewajiban sebagai Presiden dan Wakil Presiden."

Abdurrahman Wahid berpendapat, ketentuan tersebut merupakan bentuk diskriminasi dan bertentangan dengan konstitusi yang menjunjung tinggi persamaan di depan hukum dan pemerintahan. ${ }^{41}$ Dalam pertimbangan hukumnya, MK berpendapat pencantuman syarat dalam Pasal 6 UndangUndang Nomor 23 Tahun 2003 tidak dapat dipandang diskriminatif karena seorang warga negara yang terpilih sebagai Presiden dan Wakil Presiden harus memenuhi persyaratan tertentu agar kelak mampu secara rohani dan jasmani melaksanakan tugas dan kewajiban kenegaraan dimaksud. ${ }^{42}$ Menurut MK, pembatasan-pembatasan yang dilakukan undangundang sepanjang dipandang perlu karena alasan severity of their handicap sehingga tidak memungkinkan yang bersangkutan melaksanakan hak-haknya adalah hal yang dibenarkan dan tidak dapat dipandang diskriminatif. ${ }^{43}$

Dalam konteks perubahan konstitusi, putusan MK tersebut sesungguhnya telah mengubah UUD 1945 secara informal. ${ }^{44}$ Penafsiran MK dalam proses pengujian UndangUndang Nomor 23 Tahun 2003 telah mengubah makna Pasal 6 ayat (1) UUD 1945 yang awalnya menyatakan:45

“Calon Presiden dan calon Wakil Presiden harus seorang warga negara Indonesia sejak kelahirannya dan tidak pernah menerima kewarganegaraan lain karena kehendaknya sendiri, tidak pernah mengkhianati negara serta, serta mampu secara rohani dan jasmani untuk melaksanakan tugas dan kewajiban sebagai Presiden dan Wakil Presiden."

41 Putusan Mahkamah Konstitusi Nomor 008/PUU-II/2004 terkait Pengujian Undang-Undang Nomor 23 Tahun 2003 tentang Pemilihan Umum Presiden dan Wakil Presiden terhadap Undang-Undang Dasar Negara Republik Indonesia Tahun 1945, h.4-5.

42 Ibid., h. 27.

${ }^{43}$ Ibid., h.28.

${ }^{44}$ Feri Amsari, 2013. Perubahan Konstitusi Negara Kesatuan Republik Indonesia Melalui Putusan Mahkamah Konstitusi, Jakarta: Rajawali Pers, h.200.

${ }^{45}$ Ibid., h.200-201. 
Sehingga menjadi :

“Calon Presiden dan calon Wakil Presiden harus seorang warga negara Indonesia sejak kelahirannya dan tidak pernah menerima kewarganegaraan lain karena kehendaknya sendiri, tidak pernah mengkhianati negara serta, harus dalam kondisi sehat secara rohani dan jasmani untuk melaksanakan tugas dan kewajiban sebagai Presiden dan Wakil Presiden."

Dalam perkembangan selanjutnya, perubahan UUD 1945 tidak hanya terjadi dengan tiga cara yang di atas, melainkan juga terjadi dengan cara lain, yaitu melalui penandatanganan dan pengesahan perjanjian internasional menjadi hukum nasional Indonesia. Perubahan dimaksud terjadi ketika perjanjian internasional yang substansinya bertentangan dengan UUD 1945 ditandatangani dan diratifikasi menjadi hukum nasional. Salah satu perjanjian internasional tersebut adalah Piagam ASEAN.

Sebagaimana telah disinggung sebelumnya, Piagam ASEAN disahkan dan menjadi hukum nasional Indonesia melalui Undang-Undang Nomor 38 Tahun 2008 tentang Pengesahan Charter of the Association of Southeast Asian Nations (Piagam Perhimpunan Bangsa-Bangsa Asia Tenggara). Piagam ASEAN merupakan bentuk transformasi dari ASEAN yang awalnya hanya sebagai sebuah organisasi lepas tanpa diikat dengan aturan tertentu menjadi organisasi yang memiliki aturan yang jelas. ${ }^{46}$ ASEAN yang awalnya dibentuk dengan semangat hendak menyatukan aspirasi dan komitmen politik menghadapi potensi pergolakan dan pertengkaran antar negara di kawasan, ${ }^{47}$ bergeser menjadi sebuah organisasi kerjasama kawasan dalam berbagai bidang seperti politik, ekonomi, sosial dan budaya. ${ }^{48}$

${ }^{46}$ Penjelasan Umum, Undang-Undang Nomor 38 Tahun 2008 Tentang Pengesahan Charter of The Association of Southeast Asian Nations (Piagam Perhimpunan Bangsa-Bangsa Asia Tenggara).

47 Sekretariat Nasional ASEAN, ASEAN Selayang Pandang, Departemen Luar Negeri Republik Indonesia, Jakarta, 1992, h.2.

48 Penjelasan Umum, Undang-Undang Nomor 38 Tahun 2008, Op.cit. 
Sejak awal penbentukannya, ketika Perhimpunan BangsaBangsa Asia Tenggara dibentuk oleh pemerintah lima negara ${ }^{49}$ dengan penandatanganan Deklarasi ASEAN atau Deklarasi Bangkok tanggal 8 Agustus 1967, organisasi ASEAN memang sudah diproyeksikan menjadi organisasi yang akan mengikuti tuntutan perkembangan dunia. ${ }^{50}$ Sehingga, ASEAN saat ini adalah apa yang dulunya digagas pada awal pendiriannya. Salah satu tujuan pembentukan ASEAN adalah untuk mempercepat pertumbuhan ekonomi, kemajuan sosial serta pengembangan kebudayaan di kawasan melalui usaha bersama dalam semangat kebersamaan dan persahabatan untuk memperkokoh landasan sebuah masyarakat bangsa-bangsa Asia Tenggara yang sejahtera dan damai. ${ }^{51}$

Ketika ASEAN telah hendak menjadi organisasi yang memiliki aturan yang jelas, persoalan hukum yang kemudian potensial muncul adalah terjadinya konflik hukum antara hukum nasional negara-negara anggota dengan perjanjian regional ASEAN. Dalam kondisi tertentu, semangat yang terkandung dalam norma perjanjian ataupun piagam ASEAN tidak selalu sejalan dengan semangat yang terkandung dalam konstitusi negara anggota. Sekalipun misalnya pemerintah negara anggota menilai perjanjian tersebut baik bagi kepentingan negara, tetapi penilaian tersebut belum tentu sesuai dengan apa yang ditentukan baik menurut norma konstitusi negara tersebut.

Untuk membaca persoalan dimaksud lebih jauh, kiranya penting mengulas sejumlah ketentuan dalam Piagam ASEAN yang dapat dikualifisir bertentangan dengan UUD 1945. Ketentuan dimaksud adalah sebagai berikut: ${ }^{52}$

Pasal 1 ayat (5) Piagam ASEAN :

49 Lima negara dimaksud adalah: Indonesia, Malaysia, Filipina, Singapura dan Thailand, dalam Sekretariat Nasional ASEAN, Op.cit.

${ }^{50}$ Ibid., h.1-3.

${ }^{51}$ Ibid., h.1.

${ }^{52}$ Charter of The Association of Southeast Asian Nations. 
To create a single market and production base which is stable, prosperous, highly competitive, and economically integrated with effective facilitation for trade and investment in which there is free flow of goods, and services and investment; facilitated movement of business persons, professionals, talents and labour; and free flow of capital. (menciptakan pasar tunggal dan basis produksi yang stabil, makmur, sangat kompetitif, dan secara ekonomi terintegrasi dengan fasilitas yang efektif untuk perdagangan dan investasi, yang di dalamnya terdapat arus lalu lintas barang, jasa-jasa dan investasi yang bebas; terfasilitasinya pergerakan pelaku usaha, pekerja profesional, pekerja berbakat dan buruh dan arus modal yang lebih bebas."

\section{Pasal 2 ayat (2) huruf N Piagam ASEAN :}

"Adherence to multilateral trade rules and ASEAN's rules-based regimes for effective implementation of economic commitments and progressive reduction towards elimination off all barriers to regional economic integration, in a market-driven economy." (menganut peraturan-peraturan perdagangan multilateral dan rezim berbasis-aturan ASEAN untuk pelaksanaan yang efektif atas komitmen-komitmen ekonomi dan pengurangan progresif menuju penghapusan semua hambatan bagi integrasi ekonomi regional, dalam sebuah ekonomi yang dikemudikan pasar."

Konsekuensi sebagai negara yang ikut menandatangani Piagam ASEAN, segala ketentuan dalam Piagam tersebut juga berlaku bagi Indonesia. Sebab, dalam konsep perjanjian internasional, Piagam merupakan salah satu bentuk perjanjian. ${ }^{53}$ Sesuai maksud yang terkandung dalam perjanjian internasional, setiap negara anggota yang menjadi bagian dari perjanjian menerima segala akibat hukum yang diatur dalam perjanjian dimaksud $^{54}$ sejak ia diratifikasi menjadi hukum nasional. Dengan telah diratifikasinya Piagam ASEAN, asas pasar tunggal, investasi bebas dan integrasi ekonomi regional sebagaimana termuat dalam Piagam juga mengikat Indonesia secara hukum. Konsekuensinya, pengikatan Indonesia ke dalam

53 Mochtar Kusumaatmadja, 1976. Pengantar Hukum Internasional., Jakarta: Putra A Bardin, h.85.

${ }^{54}$ Ibid., h.84. 
perjanjian itu telah menyebabkan substansi Pasal 33 ayat (1) UUD 1945 berubah.

Bagaimana perubahan tersebut sebenarnya terjadi? Menjawab pertanyaan tersebut, proses terbentuknya suatu perjanjian internasional tentu amat mempengaruhi bagaimana perubahan konstitusi melalui perjanjian internasional terjadi. Sebuah perjanjian internasional terbentuk melalui tiga tahap, yaitu: ${ }^{55}$ 1). Perundingan (negotiation); 2). Penandatanganan (signature); 3). Pengesahan (ratification).

Terbentuknya Piagam ASEAN juga demikian, yaitu melalui tahap perundingan, penandatanganan dan pengesahan sehingga ia aktif berlaku sebagai sebuah perjanjian internasional untuk regional Asia Tenggara. Semua tahapan tersebut amat mempengaruhi bagaimana tiap-tiap negara membawa kepentingan masing-masing ke dalam dokumen perjanjian. Dalam konteks inilah sebuah negara masuk ke dalam perjanjian sebagai negara berdaulat dalam berhubungan dengan negaranegara peserta perjanjian lainnya dengan prinsip resiprositas atau perjanjian saling menguntungkan.

Pada tahap negosiasi tentu dipertimbangkan tentang hal mana yang menguntungkan dan bagian mana pula yang diperkirakan akan merugikan. Pada tahap itu tentu akan terjadi apa yang dinyatakan $\mathrm{MK}$, negara tidak akan mengikatkan diri pada perjanjian kalau tidak akan mendapatkan keuntungan, dan kalau suatu negara bermaksud untuk selalu mendapatkan keuntungan saja tanpa harus berkorban, maka pihak negara lain pun tidak akan menyetujui perjanjian demikian. ${ }^{56}$ Dalam konteks ini, negosiasi sesungguhnya dilakukan untuk membicarakan hal keuntungan mana yang hendak diambil negara dalam perjanjian serta hal apa pula yang dapat dikorbankan.

${ }^{55}$ Ibid., h.88-89.

56 Putusan Mahkamah Konstitusi Nomor 008/PUU-II/2004... Op.cit., h.190. 
Sikap pemerintah Indonesia dalam proses negosiasi akan sangat menentukan apakah pilihan yang diambil (terutama dalam hal apa Indonesia dalam perjanjian tersebut akan mengorbankan sesuatu) masih dalam bingkai yang diatur konstitusi? Dalam arti, konstitusi harus dijadikan panduan sekaligus batas demarkasi tentang apa yang boleh dan tidak boleh dinegosiasikan dalam merundingkan rancangan perjanjian internasional. Dalam hal-hal tertentu seperti yang terjadi dalam negosiasi pembentukan Piagam ASEAN, salah satu poin yang dikorbankan adalah asas perekonomian nasional yang tertuang dalam Pasal 33 ayat (1) UUD 1945. Apakah langkah tersebut dilakukan secara sadar oleh juru runding pemerintah yang hadir dalam proses penyusunan perjanjian atau hanya terjadi secara tanpa sengaja?

Penandatanganan Piagam sesungguhnya mengkonfirmasi bahwa poin yang disepakati dalam proses negosiasi dilakukan secara sadar oleh pemerintah Indonesia. Di mana, Piagam dimaksud ditandatangani oleh Indonesia pada tanggal 20 November 2007 pada Konferensi Tingkat Tinggi ASEAN ke-13 di Singapura. ${ }^{57}$ Dengan ditandatangi, pemerintah Indonesia pada dasarnya tidak lagi mempersoalkan substansi perjanjian serta menyetujui apa yang dimuat di dalamnya. Tidak hanya pemerintah, Dewan Perwakilan Rakyat pun telah turut menyetujuinya. Sebab, ketika Piagam akan dibuat dan ditandatangani, Presiden sebagai kepala pemerintahan mesti meminta persetujuan DPR terlebih dahulu. ${ }^{58}$ Dengan demikian, penandatanganan Piagam ASEAN merupakan sikap resmi yang juga didukung oleh lembaga perwakilan rakyat. Lebih jauh, hal itu juga dapat dikonfirmasi dengan diratifikasinya Piagam ASEAN dengan Undang-Undang. Hal mana, pembentukan dan

\footnotetext{
57 Konsideran Menimbang, Undang-Undang Nomor 38 Tahun 2008, Op.cit.

${ }^{58}$ Pasal 11 ayat (1) Undang-Undang Negara Republik Indonesia Tahun 1945.
} 
pengesahannya dilakukan secara bersama-sama oleh pemerintah dan DPR. ${ }^{59}$

Dengan telah dilaluinya semua tahapan pembentuan perjanjian, terdapatnya materi muatan yang berseberangan dengan substansi Pasal 33 ayat (1) UUD 1945 sesungguhnya merupakan langkah sadar. Hal itu berarti, dalam proses negosiasi awal pembentukan penjanjian ini, pemerintah Indonesia telah menjatuhkan pilihan untuk mengambil keuntungan tertentu dari perjanjian tersebut serta mengorbankan sesuatu yang lain, yaitu asas perekonomian nasional. Ketika pilihan itu diambil, perjanjian internasional yang diikuti tersebut telah mengubah konstitusi Indonesia.

Perubahan konstitusi yang terjadi dalam pembentukan Piagam ASEAN lebih lanjut juga mendapat legitimasi MK sebagai pelaku kekuasaan kehakiman yang berwenang menguji undang-undang terhadap UUD 1945. Gugatan atas inkonstitusionalitas Piagam ASEAN yang diratifikasi dengan Undang-Undang Nomor 38 Tahun 2008 dinyatakan ditolak. Terhadap dalil permohonan yang menilai sejumlah Pasal dalam Piagam ASEAN bertentangan dengan UUD 1945, MK salah satunya mempertimbangkan sebagai berikut: ${ }^{60}$

"Menimbang bahwa ASEAN Charter yang merupakan perjanjian antarnegara ASEAN, dari sudut pandang nasional tidak lain merupakan kebijakan makro dalam bidang perdagangan yang bisa saja kebijakan tersebut diubah apabila ternyata tidak memberi manfaat apalagi malahan mendatangkan kerugian secara nasional. Dalam kebijakan yang bersifat makro dapat saja kerugian terjadi dalam sektor atau bidang tertentu, sedangkan dalam sektor atau bidang yang lain kebijakan tersebut dapat menimbulkan keuntungan. Kebijakan sektoral dapat dilakukan untuk mengatasi kerugian sektoral yang timbul dengan mempertimbangkan konsekuensi dari pengambilan kebijakan tersebut termasuk kemungkinan reaksi dari negara lain yang

${ }^{59}$ Pasal 20 ayat (2) Undang-Undang Dasar Negara Republik Indonesia Tahun 1945.

60 Putusan Mahkamah Konstitusi Nomor 008/PUU-II/2004...Op.cit. h.193-194. 
terkena dampak dari kebijakan tersebut dan apabila ternyata kerugian yang timbul bersifat makro dan menyeluruh dapat saja kebijakan makro tersebut ditinjau kembali. Dalam hal ini, ASEAN Charter dapat ditinjau kembali, bahkan dapat diakhiri berdasarkan ketentuan Pasal 18 huruf $\mathrm{h}$ Undang-Undang Nomor 24 Tahun 2000 tentang Perjanjian Internasional yang menyatakan, "Perjanjian internasional berakhir apabila: ... h. terdapat hal-hal yang merugikan kepentingan nasional";

Jika dianalisis lebih jauh, pertimbangan tersebut lebih didasarkan pada bagaimana Piagam ASEAN tersebut kelak dilaksanakan. MK sesungguhnya bukan memberikan pertimbangan terkait konstitusionalitas norma, melainkan menilai tentang bagaimana kemudian ketentuan-ketentuan yang tertuang dalam Piagam ASEAN suatu saat dapat ditinjau kembali jika ternyata merugikan kepentingan Indonesia. Dalam konteks ini, MK seakan menghindar dari memberi penilaian terhadap substansi norma Piagam ASEAN yang diuji dengan UUD 1945 sebagai peraturan yang lebih tinggi. MK sebagai lembaga yang diproyeksikan tidak hanya terbatas melakukan pengujian konstitusionalitas terbatas pada apa yang tertulis dalam naskah UUD, melainkan juga didasarkan pada konstitusi tidak tertulis yang terdapat dapat nilai-nilai yang hidup dalam praktik ketatanegaraan, ${ }^{61}$ justru tidak melihat norma Piagam ASEAN secara lebih kritis terkait kepentingan perekonomian nasional Indonesia.

Terlepas dari itu, hal yang dapat dipastikan dari semua proses tersebut adalah, baik Pemerintah, DPR maupun lembaga kekuasaan kehakiman yang diberi kewenangan melindungi konstitusi sama-sama bersepakat untuk menerima Piagam ASEAN sebagai hukum nasional Indonesia. Penerimaan itu merupakan pendapat resmi negara, di mana juga diterima oleh sebagian besar rakyat Indonesia. Penerimaan terhadap perjanjian internasional itulah kemudian yang berimplikasi

61 Jimly Asshiddiqie, 2005. Hukum Acara Pengujian Undang-Undang, Jakarta: Sekretariat Jenderal dan Kepaniteraan Mahkamah Konstitusi, h.7-8. 
terhadap berubahnya Pasal 33 UUD 1945 secara informal, atau melalui cara-cara yang tidak diatur dalam Pasal 37 UUD 1945.

Jika proses perubahan UUD 1945 melalui perjanjian internasional dimaksud dilihat dari sudut pandang tata cara perubahan konstitusi menurut Wheare, perubahan yang terjadi berada di luar konsep yang dikemukannya. Dalam arti, perubahan konstitusi melalui perjanjian internasional merupakan salah satu cara lain dari bagaimana konstitusi diubah.

Di satu sisi, perubahan konstitusi melalui perjanjian internasional tidak dapat dimasukkan menjadi bagian dari tiga cara perubahan konstitusi yang dikemukakan Wheare sebelumnya. Sebab perubahan melalui perjanjian bukanlah perubahan formal, bukan perubahan melalui lembaga yudisial, dan bukan pula perubahan melalui kebiasaan. Di sisi lain, perubahan konstitusi melalui perjanjian internasional dapat dikategorikan sebagai perubahan konstitusi secara informal. Di mana, menurut Wheare, perubahan informal terjadi karena adanya kekuatan-kekuatan yang mampu menimbulkan perubahan konstitusi itu sendiri. ${ }^{62}$

Dalam konteks ini, kekuatan-kekuatan politik dalam proses negosiasi ketika perjanjian dirumuskan merupakan faktor pendukung mengapa muatan suatu perjanjian internasional justru menekan norma-norma konstitusi negara. Suatu negara "ditekan" untuk menegosiasikan sebagian kepentingan nasionalnya agar perjanjian dapat diwujudkan. Atas tekanan dimaksud, pemerintah negara membiarkan sebagian kepentingan konstitusionalnya dilanggar demi untuk memperoleh keuntungan lain dari sebuah hubungan internasional yang diwujudkan dalam perjanjian berupa Piagam ASEAN.

Sekarang tibalah saat membahas bagaimana kedaulatan negara yang dikonkritkan melalui konstitusi sebagai hukum dasar dapat dipertahankan ketika negara tersebut ikut menjadi

${ }^{62}$ Feri Amsari, Op.cit., h.50. 
pihak dalam sebuah perjanjian multilateral dengan sejumlah negara, dalam hal ini perjanjian berupa Piagam ASEAN.

\section{Perjanjian Internasional dan Kedaulatan Negara}

Secara istilah, kata "kedaulatan" diartikan sebagai superioritas saja, tetapi ketika diterapkan pada negara, kata tersebut berarti superioritas dalam arti khusus, yaitu superioritas yang mengisyaratkan adanya kekuasaan untuk membuat hukum (law-making power). ${ }^{63}$ Dalam perkembangannya, kedaulatan dimaksudkan secara sederhana untuk menunjuk pada suatu "kekuasaan tertinggi". ${ }^{64}$ Tidak jauh berbeda dengan itu, Grotius mengatakan kekuasaan tertinggi untuk memerintah ini dinamakan kedaulatan. Menurutnya, kedaulatan dipegang oleh orang yang tidak tunduk pada kekuasaan orang lain, sehingga tidak dapat diganggu gugat oleh kemauan manusia. ${ }^{65}$

Jean Bodin dalam Six Lives de la Republique mengemukakan, kedaulatan adalah kekuasaan yang mengatasi warga negara dan anak buah, malahan mengatasi undangundang, atau dengan kalimat lain ia katakan, kedaulatan adalah kekuasaan yang penuh dan langgeng kepunyaan satu Republik. ${ }^{66}$ Ia juga menekankan, salah satu aspek penting kedaulatan adalah kekuasaan untuk membuat hukum sebagai sarana agar kekuasaan dapat dijalankan secara efektif. ${ }^{67}$

${ }^{63}$ C.F. Strong, 2004. Konstitusi-Konstitusi Politik Modern Kajian Tentang Sejarah \& Bentuk-bentuk Konstitusi Dunia, Bandung: Penerbit Nuansa dengan Penerbit Nusamedia, h.9.

${ }^{64}$ Hendra Nurtjahjo, 2006. Filsafat Demokrasi, Jakarta: Bumi Aksara, h.31.

65 Arief Budiman, 2002. Teori Negara, Negara, Kekuasaan dan Ideologi, Jakarta: PT Gramedia Pustaka Utama, h.12.

${ }^{66}$ Muhammad Yamin, 1952. Proklamasi dan Konstitusi Republik Indonesia, Djakarta: Djambatan, h.115, dalam Moh. Mahfud MD., Op.cit., h.104.

${ }^{67}$ W. Friedmann, 1953. Legal Theory (Third Edition), London: Stevens \& Sons Limited, h.416. Dalam konteks kekuasaan membuat hukum, Bodin menyamakan antara hukum dengan Undang-Undang. 
Bagi Bodin, kedaulatan merupakan ciri sekaligus atribut negara yang membedakannya dari persekutuan-persekutuan lainnya. ${ }^{68}$ Oleh karenanya, kedaulatan merupakan hakekat dari sebuah negara. Kedaulatan merupakan essensialia setiap kesatuan politik yang disebut negara. Tanpa kedaulatan, tidak ada negara. ${ }^{69}$ Lebih jauh, Bodin juga menguraikan tiga unsur kedaulatan, yaitu: ${ }^{70}$

1. Kekuasaan itu bersifat tertinggi, tidak ada kekuasaan yang lebih tinggi;

2. Mutlak dan sempurna dalam arti tidak terbatas dan tidak ada kekuasaan lain yang membatasinya;

3. Utuh, bulat, dan abadi, dalam arti tidak terpecah-pecah dan tidak terbagi-bagi.

Tidak jauh berbeda dengan Bodin, J. J. Rousseau mengidentifikasi tiga sifat konsep kedaulatan, yaitu: ${ }^{71} 1$ ). Kesatuan (unite), bersifat monistis; 2). Bulat dan tak terbagi (indivisibilite); 3). Tak dapat dialihkan (inalienabilite); 4). Tidak dapat berubah (imprescriptibilite). Sedangkan Austin dalam The Province of Jurisprudence Determined yang diterbitkan tahun 1832 mengatakan bahwa kedaulatan adalah: ${ }^{72}$

"If a determinate human superior, not in a habit of obedience to a like superior, receiver habitual obedience from the bulk of a giver society, that determinate superior as sovereign in that society, and the society (including the superior) ia a society, political and independent.

Lebih jauh Austin menilai bahwa yang berdaulat adalah "legibus soluta". Subjek yang berdaulat adalah pembentuk hukum yang tertinggi (supreme legislator) dan hukum posisit adalah hukum yang dibuat oleh yang berdaulat itu. ${ }^{73}$ Jadi,

${ }^{68}$ F. Isjwara, 1966. Pengantar Ilmu Politik, Bandung: Penerbit Bina Cipta, h.94.

${ }^{69} \mathrm{Ibid}$.

70 Jimly Asshiddiqie, 2005. Konstitusi \& Konstitusionalisme Indonesia, Jakarta: Konstitusi Press, h.126.

${ }^{71}$ Ibid., h.127.

72 Samidjo, 1986. Ilmu Negara, Bandung: CV. Armico, h.141.

${ }^{73} \mathrm{Ni}^{\prime}$ matul Huda, 2010. Ilmu Negara, Jakarta: Rajawali Pers, h.171. 
berdaulat menurutnya adalah kekuasaan tertinggi berada di atas hukum. Lebih lanjut ia mengemukakan empat ciri kedaulatan berikut, yaitu $:^{74}$

1. Non-subordinate, that is (a) sovereign power cannot be conferred by a law; and (b) this legislative power cannot be revoked by law;

2. Illimitable, that is (a) the sovereign legislative power legally illimitable, is to the power to legislative and law whatsoever; and (b) the sovereign cannot be made subject to legal duties in the exercise of his legislative power;

3. Unique, for every legal system there is (a) one and (b) only one non-subordinate and illimitable legislative power;

4. United, this legislative power is in the hand of one person or one body of persons.

Berbagai ciri kedaulatan sebagaimana dikemukan beberapa pakar di atas dalam perkembangannya mendapat kritik dari banyak ahli, salah satunya H. L.A. Hart. Menurutnya, ketidakterbatasan kedaulatan sebagaimana dikemukakan Bodin dan Rousseau tidak lagi dapat dipertahankan. ${ }^{75}$ Sebagaimana juga dikemukakan Starke, kedaulatan pada saat ini mempunyai arti yang lebih sempit dari apa yang dipahami pada abad kedelapan belas. ${ }^{76}$ Menurutnya, konsep kekuasaan tertinggi saat ini dapat saja dibagi dan dibatasi melalui pengaturan yang ditentukan dalam konstitusi. ${ }^{77}$ Dengan demikian, kekuasaan tertinggi yang terbagi itu kemudian dijelmakan menjadi aturan dasar yang disebut dengan konstitusi.

Di samping berbagai ciri konsep kedaulatan di atas, para ahli juga membahas tentang lingkup keberlakuannya. Sehubungan dengan itu, dirumuskanlah dua jenis kedaulatan, yaitu kedaulatan ke luar dan kedaulatan ke luar. Kedaulatan ke

\footnotetext{
${ }^{74}$ Jimly Asshiddiqie, Op.cit., h.128.

${ }^{75}$ Ibid., h.133.

${ }^{76}$ J. G. Starke, Op.cit., h.132.

77 Jimly Asshiddiqie, Op.cit., h.134.
} 
luar (eksternal) merupakan kedaulatan negara dalam berhadapan dengan negara lain secara eksternal. ${ }^{78}$ Sedangkan kedaulatan ke dalam (internal) adalah kedaulatan negara dalam menyelenggarakan kekuasaan dalam negara.

Berdasarkan teori kedaulatan tersebut, sebagai atribut negara yang mesti ada, kedaulatan atau kekuasaan tertinggi diposisikan sebagai mahkota negara. Kekuasaan tertinggi dimaksud tidak berada di bawah kekuasaan lainnya. ${ }^{79}$ Ia merupakan kekuasaan yang bebas.

Kedaulatan atau kekuasaan tertinggi tersebut dimanivestasikan dalam suatu kontrak politik, ekonomi, dan hukum yang disebut dengan Undang-Undang Dasar atau konstitusi. Sebagai kontrak kekuasaan, konstitusi mesti dipatuhi oleh siapapun yang menjalankan kekuasaan. Dalam arti, pelaksanaan kekuasaan negara oleh pemegang kekuasaan harus tunduk pada konstitusi sebagai perwujudan kekuasaan tertinggi rakyat dalam negara. Kepatuhan pada konstitusi yang diwujudkan dalam kesediaan menerima keputusan golongan terbanyak atau keputusan pemerintah menurut konstitusi disebut Mac Iver sebagai kehendak untuk negara, yaitu kehendak untuk mempertahankannya. ${ }^{80}$

Dalam konteks itu, tindakan apapun yang akan diambil oleh pembentuk maupun pelaksana undang-undang, ia wajib tunduk pada konstitusi. Ketentuan-ketentuan yang dimuat di dalamnya tidak boleh disimpangi, baik dalam penyelenggaraan kekuasaan ke dalam atau pun ke luar. Lebih-lebih lagi negara yang menganut prinsip kedaualatan rakyat dan meletakkan konstitusi sebagai supremasi tertinggi. Menyimpangi konstitusi sama halnya dengan niat mengkhianati rakyat dan meruntuhkan negara.

${ }^{78}$ Ibid., h.139.

79 Khairul Fahmi, 2011. Pemilihan Umum dan Kedaulatan Rakyat, Jakarta: Rajawali Pers, h.41.

${ }^{80}$ R. M. Mac Iver, 1980. Negara Modern, Jakarta: Aksara Baru, h.18. 
Artinya, kewajiban untuk tunduk pada konstitusi sebagai wujud kekuasaan tertinggi tidak hanya dalam penyelenggaraan kekuasaan ke dalam negara, melainkan juga berlaku ketika pemegang kekuasaan melaksanakan hubungan negara dengan negara lain. Hubungan dalam bentuk perjanjian dengan negara lain tidak dapat dijadikan alasan untuk tidak patuh atau menyimpangi apa yang telah diatur tegas dalam konstitusi.

Jadi, secara operasional, teori kedaulatan itu dilaksanakan dengan menjalankan kekuasaan negara dalam bingkai normanorma konstitusi, baik dalam melaksanakan urusan pemerintahan ke dalam maupun urusan pemerintahan ke luar atau hubungan dengan negara lain. Konstitusi merupakan hukum dasar yang mesti dijadikan panduan dalam membuat undang-undang ataupun perjanjian internasional yang melibatkan negara yang bersangkutan. Bagir Manan bahkan menegaskan, meskipun UUD 1945 tidak menunjuk batas-batas dalam melaksanakan perjanjian internasional, perlu disadari bahwa UUD 1945 (dan Pembukaan) merupakan pembatasan dalam memasuki suatu masalah dan hubungan internasional. ${ }^{81}$

Uraian konsep kedaulatan maupun supremasi konstitusi di atas sesungguhnya hanya mengikat satu negara dan/atau pemerintahan negara tertentu saja. Dalam arti, konstitusi hanya dapat menjangkau internal negara, tidak untuk subjek di luar itu. Dalam hal ini, konstitusi negara tertentu tidak memaksa negara lain untuk juga tunduk kepadanya. Sementara di luar itu, terdapat hukum yang mengatur hubungan antar negara yang dibentuk atas dasar perjanjian antar negara. Perjanjian tersebut juga mengikat seluruh komponen saat negara mengikatkan diri padanya.

Lalu, bagaimana posisi kedaulatan negara ketika terdapat dua tata hukum yang berlaku secara bersamaan, yaitu konstitusi dan hukum internasional? Sesuai pandangan yang dikemukan di atas, dalam keikutsertaannya dalam perjanjian internasional, pemerintahan negara terikat dan tunduk pada konstitusi.

${ }^{81}$ Bagir Manan, Pertumbungan dan Perkembangan... Op.cit., h.82. 
Apapun perjanjian internasional yang hendak diikuti, ia harus sesuai dengan konstitusi. Jika tidak, tindakan tersebut dapat dinilai sebagai pelanggaran konstitusi dan sumpah jabatan seorang Presiden sebagai kepala pemerintahan yang bertanggung jawab atas pengesahan perjanjian internasional. Pelanggaran dimaksud dapat dinilai sebagai sebuah pengkhianatan terhadap negara dan bisa berujung pada diberhentikannya Presiden. ${ }^{82}$

Sementara pandangan lain, Franck misalnya menyatakan kedaulatan sesungguhnya ditentukan oleh dua faktor, yaitu: kekuasaan dari suatu negara yang berdaulat diikat dengan konstitusinya dan juga oleh hukum internasional. ${ }^{83}$ Dalam arti, kedaulatan memiliki dua dimensi yaitu dimensi internal (diikat konstitusi) dan dimensi eksternal yang diatur dan tunduk pada hukum internasional. ${ }^{84}$ Sejalan dengan apa yang diistilahkan dengan kedaulatan ke dalam dan ke luar sebagaimana disinggung sebelumnya, pendapat Franck menegaskan bahwa dua jenis hukum tersebut manifestasi dari kedaulatan negara. Di mana, konstitusi merupakan manifestasi dari kontrak pemegang kekuasaan tertinggi dalam negara (rakyat), sementara perjanjian internasional merupakan perwujudan dari kekuasaan pemerintahan negara atas nama negara yang dipimpinnya untuk berhubungan dengan negara lain. Dengan demikian, ia meletakan konstitusi setara dengan hukum internasional yang diikuti suatu negara.

Dua pandangan tersebut kiranya dapat dipertemukan dengan mengamini ajaran Monisme Hans Kelsen dalam menjelaskan kesatuan hukum nasional dan hukum internasional. Menurutnya, dengan ruang dan waktu berlaku yang sama, hukum nasional dan hukum internasional tidak dapat dikatakan sebagai sistem norma yang terpisah dan berdiri 1945.

82 Pasal 7 A Undang-Undang Dasar Negara Republik Indonesia Tahun

83 Ade Maman Suherman, 2003. Organisasi Internasional dan Integrasi Ekonomi Regional dalam Perspektif Hukum dan Golbalisasi, Jakarta: Penerbit Ghalia, h.29.

${ }^{84}$ Ibid., h.29. 
sendiri-sendiri. ${ }^{85}$ Secara logis, tidak mungkin untuk menerima bahwa norma-norma yang berlaku secara bersamaan milik sistem yang berbeda dan berdiri sendiri-sendiri. ${ }^{86}$ Sesuai pendapat tersebut, konstitusi sebagai hukum nasional sesungguhnya berada dalam satu sistem norma dengan perjanjian internasional.

Dalam satu kesatuan sistem norma, bagaimana dua tata hukum tersebut berinteraksi secara harmoni, sementara kepentingan masing-masing negara dalam sebuah perjanjian internasional justru berbeda-beda? Di mana, perbedaan kepentingan tiap-tiap negara potensial menyebabkan munculnya pertentangan antara apa yang hendak dimuat dalam perjanjian internasional dengan ketentuan konstitusinya. Apalagi perbedaan kepentingan antara negara maju dengan apa yang disebut dengan negara berkembang. Hikmanto Juwana mengemukan, hukum internasional sesungguhnya berada dalam konflik kepentingan ekonomi antara negara. ${ }^{87}$ Negara Maju menghendaki agar hukum internasional tidak diutak-atik demi melindungi kepentingan ekonominya, sementara Negara Berkembang menghendaki perubahan-perubahan mendasar dalam hukum internasional sehingga mencerminkan nilai-nilai yang dianut oleh mayoritas penduduk dunia. ${ }^{88}$

Dalam konteks pertarungan ekonomi itulah kemudian negosiasi perjanjian internasional kadang disusun. Di satu sisi, perjanjian internasional yang melibatkan negara-negara maju di kawasan menghendaki kepentingan ekonomi mereka tetap mendominasi, di sisi lain konstitusi negara berkembang seperti Indonesia justru memberikan proteksi agar perjanjian internasional tidak merugikan kepentingan rakyat. Oleh karena

${ }^{85}$ Hans Kelsen, 1961. General Theory of Law and State, Translated by Anders Wedberg, New York: Russel \& Russel, Op.cit., h.363.

${ }^{86}$ Ibid.

87 Hikmahanto Juwana, 2011. Hukum Internasional dalam Konflik Kepentingan Ekonomi Negara Berkembang dan Negara Maju, Pidato Upacara Pengukuhan Sebagai Guru Besar Tetap dalam Ilmu Hukum Internasional pada Fakultas Hukum Universitas Indonesia, Depok, h.5.

${ }^{88}$ Ibid., h.5-6. 
itu, pada titik tertentu, dilatari pertarungan ekonomi antar negara, antara konstitusi dan perjanjian internasional akan selalu dalam posisi saling tarik-menarik.

Dalam kondisi itu, Kelsen mengatakan, ketika hukum internasional dan hukum nasional berinteraksi dan membentuk sistem terpadu, maka timbal-balik antara dua hukum tersebut mesti menghasilkan satu bentuk atau formulasi tersendiri. ${ }^{89}$ Lalu, formulasi apa yang kemudian dapat terbentuk dari interaksi kepatuhan pada konstitusi dan kebutuhan negara untuk berhubungan dengan negara lain melalui perjanjian internasional?

Menjawab pertanyaan tersebut, kedudukan masingmasing tata hukum, baik konstitusi maupun perjanjian tentu amat menentukan. Dengan mengikuti ajaran Monisme, kedudukan konstitusi dan perjanjian harus diletakkan secara jelas. Hal itu diperlukan guna menentukan bagaimana jalan penyelesaian jika terjadi pertentangan antaran perjanjian internasional dengan konstitusi sebuah negara. Terkait hal itu, pertanyaan yang hendak dijawab adalah, apakah hubungan keduanya bersifat hirakhis atau yang satu merupakan subordinat dari yang lain?

Dalam satu sudut pandang, sulit sesungguhnya untuk mengkualifikasi dua tata hukum tersebut dalam satu sistem hirarkhi norma. Sebab, sekalipun keduanya hendak diletakkan dalam satu sistem norma, namun sebagaimana dikatakan Kelsen, dalam kenyataannya hukum internasional adalah hukum antar-negara, sementara hukum nasional adalah hukum satu negara. ${ }^{90}$ Walaupun hukum internasional memiliki ruang yang berhimpitan dengan hukum nasional, namun hukum nasional tidak memiliki daya berlaku seluas yang dimiliki hukum internasional. Dalam konteks itu, tentu ada perbedaan yang menyulitkan keduanya diletak secara hirarkhis.

89 Hans Kelsen, 1992. Introduction to The Problems of Legal Theory, Clarendon Paperbacks, New York: Oxford University Press, h.113.

${ }^{90}$ Hans Kelsen, General Theory... Op.cit., h.365. 
Sementara dari sudut pandang yang lain, dengan tidak adanya bidang masalah yang dapat diatur hanya oleh hukum nasional saja dan tidak oleh hukum internasional, ${ }^{91}$ dalam arti tidak ada batas demarkasi antara materi muatan yang akan dimuat dalam hukum nasional dan internasional, maka meletakkan keduanya dalam sistem sistem hirakhi norma menjadi keniscayaan. Dalam konteks itu, Kelsen berpandangan bahwa hubungan hirakhis antara norma hukum internasional dan nasional mesti dilihat dari validitas terakhir dari tata hukum tersebut. Menurutnya, tata hukum internasional merupakan landasan validitas terakhir dari tata hukum nasional. ${ }^{92}$ Atas dasar itu, ia meletakkan hukum internasional sebagai hukum yang lebih tinggi dibandingkan hukum nasional.

Pendapat tersebut tentunya tidak dapat diterima semua pihak, terutama yang tidak setuju menempatkan hukum nasional sebagai subodinasi hukum internasional. Bagaimanapun, kedaulatan negara dalam membentuk hukum tidak dapat diletakkan di bawah bayang-bayang perjanjian yang dibuat negara dengan negara lainnya. Lagi pula, ada tidaknya atau berlaku tidaknya hukum internasional sangat bergantung pada kemauan negara. ${ }^{93}$ Lalu bagaimana mungkin hukum internasional diletak di atas hukum nasional, di mana konstitusi merupakan hukum tertingginya?

Sampai saat ini, perdebatan antara aliran monisme dan dualisme seperti tampak dalam uraian di atas belumlah ada ujungnya. Oleh karena itu, terkait hubungan hirakhis hukum nasional dan internasional akan sangat bergantung pada sudut pandang yang digunakan. Tanpa memperpanjang pembahasan tersebut, adanya baiknya kembali pada bahasan bagaimana meletakkan hukum nasional dan internasional dalam sebuah tatanan yang harmoni atau setidaknya bagaimana menyelesaikan kasus jika hukum nasional berkonflik dengan hukum internasional?

\footnotetext{
${ }^{91}$ Hans Kelsen, Ibid., h.365.

${ }^{92}$ Hans Kelsen, Ibid., h.368.

${ }^{93}$ Muchtar Kusumaadmadja, Op.cit., h.40.
} 
Dalam pandangan aliran Monisme, konflik antara hukum internasional dan hukum nasional merupakan konflik antara norma yang lebih tinggi dengan norma yang lebih rendah. Jika terjadi konflik antara keduanya, undang-undang tersebut tidak dapat dinilai sebagai norma yang valid. ${ }^{94}$ Hanya saja, hukum internasional tidak menetapkan prosedur untuk membatalkan norma-norma hukum nasional yang bertentangan dengan hukum internasional. ${ }^{95}$ Dalam hal itu, sangat mungkin pengadilan diberi kekuasaan untuk menerapkan atau tidak menerapkan undang-undang yang bertentangan dengan norma yang lebih tinggi. ${ }^{96}$ Sehubungan dengan itu, tidak ada jalan keluar sesungguhnya terhadap penyelesaian konflik norma selain ancaman sanksi bagi negara yang tidak mematuhi norma yang diperjanjikan.

Selain itu, pandangan tersebut tentu hanya bisa digunakan jika sebuah hukum nasional lahir kemudian dibandingkan hukum internasional, akan tetapi jika perjanjian internasional yang lahir lebih kemudian dibandingkan hukum nasional (konstitusi), tentu negara tersebut tidak dapat dipaksa untuk membatalkan konstitusinya. Pada ranah ini, sulit sesungguhnya untuk mengukur mana yang tinggi antara hukum nasional dan hukum internasional. Hal yang mungkin diatur hanyalah sanksi bagi negara yang tidak menindaklanjuti isi perjanjian, dan bukan dengan dilakukannya pembatalan norma melalui mekanisme internasional.

Pada akhirnya, aspek yang akan menentukan bagaimana konstitusi negara tetap dihormati dalam pembentukan hukum internasional terpulang kepada pemerintahan negara yang bersangkutan. Di sinilah arti penting proses diplomasi dalam melahirkan perjanjian internasional yang berpihak pada kepentingan nasional sesuai dengan konstitusi. Pada saat yang sama, pembulatan, penyesuaian, pemantapan sebuah konsep perjanjian internasional amat penting dilakukan sebelum

\footnotetext{
${ }^{94}$ Hans Kelsen, Op.cit, h.371.

${ }^{95}$ Ibid., h.372.

96 Ibid., h.371.
} 
perjanjian ditandangani. ${ }^{97}$ Langkah tersebut merupakan kata kunci agar kedaulatan negara tetap dapat dijaga sesuai konstitusi ketika negara tersebut terlibat dan terikat dalam suatu perjanjian internasional.

Selain itu, terjaga atau tidaknya kedaulatan negara akan sangat bergantung pada komitmen pemerintah dan lembaga perwakilan rakyat dalam membentuk perjanjian internasional. Kalaupun seandainya sebuah perjanjian dibuat, di mana sebagian isinya bertentangan dengan UUD 1945, lalu kemudian perjanjian tersebut tetap diterima, langkah yang dilakukan pemerintah tentunya tidak akan dianggap melanggar UUD $1945.9^{8}$ Sebaliknya jika perjanjian yang tidak sesuai dengan konstitusi ditolak oleh rakyat, saat itu pemerintah maupun DPR dapat dituduh melakukan pelanggaran konstitusi dan harus bersiap untuk menerima segala akibat hukum dan politik dari pelanggaran tersebut.

Selanjutnya, apakah bentuk hukum yang dipilih dalam rangka meratifikasi perjanjian internasional akan mempengaruhi kedudukannya dalam tata hukum Indonesia? Dalam Pasal 9 ayat (2) Undang-Undang Nomor 24 Tahun 2000 tentang Perjanjian Internasional diyatakan bahwa pengesahan perjanjian internasional dilakukan dengan Undang-Undang atau Keputusan Presiden. ${ }^{99}$ Dalam arti, jika sebuah perjanjian seperti Piagam ASEAN disahkan dengan Undang-Undang atau

\footnotetext{
97 Ade Irawan Taufik, Bola Panas Putusan Pengujian Undang-Undang Pengesahan Piagam ASEAN, http://www.rechtsvinding.bphn.go.id/jurnal online/Bola\%20Panas\%20Putusan $\% 20 \mathrm{Pe}$ ngujian \%20UU\%0Asean\%20Charter \%20for\%20artikel\%20Kompas.pdf, diakses tanggal 1 November 2014.

${ }_{98}$ Dalam konteks ini, yang terjadi adalah perubahan konstitusi secara informal.

99 Terdapat ciri baru dari pengesahan perjanjian internasional menggunakan bentuk hukum Keputusan Presiden atau Peraturan Presiden yaitu mayoritas perjanjian bilateral. Sedangkan bentuk hukum undang-undang digunakan untuk meratifikasi perjanjian internasional yang sifatnya multilateral. Dalam Ni Ketut Aprilyawathi, Wewenang Mahkamah Konstitusi dalam Pengujian Undang-Undang Hasil Ratifikasi Perjanjian Internasional yang Bersifat Multilateral, Jurnal Yuridika: Volume 30 No. 1, Januari-April 2015, h.108.
} 
Keputusan Presiden, apakah kemudian ia secara hirakhis akan berada di bawah UUD 1945?

Secara formal memang harus demikian. Sebab, dengan Undang-Undang atau Keputusan Presiden-lah suatu perjanjian internasional berlaku sebagai hukum nasional. Bagir Manan mengatakan, ketika perjanjian internasional diberi bentuk undang-undang, maka segala tata cara pembentukan undangundang berlaku pada UU ratifikasi. Demikian juga halnya dengan Piagam ASEAN yang berlaku sebagai hukum nasional Indonesia dengan sebuah Undang-Undang, dan segala pengaturan tentang pembentukan atau konsekuensi pengujian terhadap UU tersebut juga berlaku. ${ }^{100}$ Ketika telah disahkan menjadi hukum nasional, siapapun dalam negara Indonesia terikat dengannya. Sebagai akibatnya, setiap warga negara pun berhak menguji konstitusionalitasnya.

Hanya saja, keterikatan Indonesia dalam Piagam ASEAN sesungguhnya bukan hanya tergantung pada bentuk hukum pengesahannya. Sebab, Undang-Undang hanyalah bentuk hukum pengesahan semata. Sementara keterikatan Indonesia dalam perjanjian adalah karena Indonesia menjadi pihak sekaligus subjek yang telah menyetujui perjanjian. Dalam konteks itu, Indonesia terikat sesuai asas pacta sund servanda. ${ }^{101}$ Oleh karenanya, sekalipun terdapat mekanisme pengujian undang-undang terhadap Undang-Undang, perjanjian internasional yang diratifikasi menggunakan undang-undang tidaklah dapat dibatalkan secara serta-merta ketika UndangUndang yang diratifikasi dinyatakan bertentangan dengan UUD 1945. Putusan pembatalan suatu Undang-Undang Ratifikasi hanya akan berdampak pada hilangnya fungsi Undang-Undang Ratifikasi untuk mengesahkan perjanjian. ${ }^{102}$

100 Andi Sandi Ant. dan Agustina Merdekawati, Konsekuensi Pembatalan Undang-Undang Ratifikasi Terhadap Keterikatan Pemerintah Indonesia pada Perjanjian Internasional, Mimbar Hukum, Volume 24, Nomor 3, Oktober 2012 , h.468.

${ }^{101}$ Putusan Mahkamah Konstitusi Nomor 33...Op.cit., h.195.

102 Andi Sandi Ant dan Agustina Merdekawati, Op.cit., h.469. 
Adapun terhadap perjanjian (Piagam ASEAN) yang menjadi lampiran, di mana Indonesia berstatus menjadi state party di dalamnya tidak serta merta hilang. Indonesia akan tetap terikat untuk melaksanakan semua ketentuan yang ada dalam perjanjian sepanjang Indonesia masih tercatat sebagai negara pihak. ${ }^{103}$ Kemudian untuk dapat keluar dari perjanjian, sesuai Pasal 54 Konvensi Wina 1969, mekanisme pengakhiran suatu perjanjian tunduk pada ketentuan yang diatur dalam perjanjian atau dengan persetujuan semua pihak sesudah berkonsultasi denga negara-negara yang berjanji lainnya, yaitu negara-negara peserta dalam perjanjian Piagam ASEAN. Faktanya, dengan ditolaknya permohonan pengujian UU Ratifikasi Piagam ASEAN, perjanjian tersebut berlaku sebagai hukum nasional, Indonesia tidak keluar sebagai negara pihak dalam perjanjian.

Oleh karena itu, tindak lanjut dari perjanjian tersebut tentu akan diatur lebih jauh oleh negara-negara pihak, termasuk Indonesia. Tindak lanjut perjanjian internasional yang secara substansi bertentangan dengan UUD 1945 akan merugikan hak konstitusional warga negara. Oleh karena itu, pengujian undang-undang terkait pengesahan perjanjian internasional harus tetap dilakukan dalam rangka bagaimana mekanisme pengujian undang-undang di Mahkamah Konstitusi dapat menjadi alat kontrol bagi pemerintah dalam menandatangani dan mengesahkan perjanjian internasional. Dalam hal ini, sikap MK sebagai pengawal konstitusi yang menyatakan berwenang mengadili pengujian Undang-Undang tentang Ratifikasi sudah pada tempatnya. Selain itu, jika pengujian Undang-Undang dinilai lebih rawan terhadap kompleksitas persoalan yang muncul jika pengujian undang-undang ratifikasi dikabulkan MK, ruang judicial preview semestinya dibuka untuk perjanjianperjanjian internasional yang bersifat strategis bagi kepentingan negara dan supremasi Undang-Undang Dasar 1945 sebagai konstitusi negara.

103 Ibid., h.472. 


\section{KESIMPULAN}

Berdasarkan pembahasan di atas, dapat disimpulkan sebagai berikut ini. Pertama, sebagai hukum dasar atau hukum tertinggi, perubahan UUD 1945 tidak hanya terjadi melalui perubahan formal melalui mekanisme yang diatur dalam Pasal 37 UUD 1945, melainkan juga diubah dengan cara-cara informal seperti melalui kebiasaan dan penafsiran hakim. Bahkan dalam perkembangan terbaru, UUD 1945 juga diubah melalui mekanisme informal lainnya, yaitu melalui pengesahan perjanjian internasional, dalam hal ini Piagam ASEAN. Perubahan UUD 1945 melalui perjanjian merupakan mekanisme perubahan informal yang terpisah dari beberapa cara yang pernah ada sebelumnya. Oleh karena itu, cara perubahan ini merupakan cara lain yang mesti dicatat sebagai salah satu mekanisme perubahan konstitusi secara informal yang melengkapi apa yang pernah dikemukakan Wheare. Kedua, Perubahan UUD 1945 melalui perjanjian internasional dapat mereduksi eksistensi konstitusi sebagai pengejawantahan kekuasaan tertinggi negara. Pada saat yang sama, hal itu dapat menimbulkan konflik hukum antara konstitusi dan perjanjian internasional. Sekalipun ketentuan konstitusi tidak serta-merta batal akibat disahkannya perjanjian internasional, namun jika perjanjian yang notabene bertentangan dengan UUD 1945 tersebut dilaksanakan, justru akan merugikan kepentingan rakyat. Hal itu tentu akan berimplikasi pada dilema pemerintah dalam menjaga kepentingan rakyat di satu sisi dan menjalankan perjanjian internasional di sisi lain.

Untuk menghindari konflik hukum yang potensial muncul serta menghindari peluang Indonesia dikenai sanksi sesuai perjanjian internasional, maka proses negosiasi, penandatanganan dan pengesahan perjanjian internasional haruslah dilakukan dengan mengacu pada norma-norma konstitusi sebagai hukum dasar negara.

Selain itu, penandatanganan dan pengesahan perjanjian internasional yang secara substansi sangat potensial bertentangan dengan UUD 1945 tidak hanya cukup dilakukan 
oleh Presiden dengan persetujuan DPR, melainkan perlu dilakukan judial preview oleh Mahkamah Konstitusi. Kewenangan judial preview terkait perjanjian internasional yang bersifat strategis perlu diberikan kepada MK dalam rangka menjaga agar maruah konstitusi tetap terpelihara dengan baik.

\section{REFERENSI:}

\section{A. Buku}

Suherman, Ade Maman. 2003. Organisasi Internasional dan Integrasi Ekonomi Regional dalam Perspektif Hukum dan Golbalisasi, Jakarta: Penerbit Ghalia.

Budiman, Arief. 2002. Teori Negara, Negara, Kekuasaan dan Ideologi, Jakarta: PT Gramedia Pustaka Utama.

Dicey, A.V. 1971. An Introduction to Study of the Law of the Constitution, London, English Language Book Society and Mac Millan.

Manan, Bagir. 1995. Pertumbuhan dan Perkembangan Konstitusi Suatu Negara, Bandung, Mandar Maju.

Manan, Bagir. 2006. Konvensi Ketatanegaraan, Yogyakarta, FH UII Press.

Manan, Bagir.; \& Kuntana Magnar, 1997. Beberapa Masalah Hukum Tata Negara Indonesia, Bandung, Penerbit Alumni.

Strong, C.F. 2004. Konstitusi-Konstitusi Politik Modern Kajian Tentang Sejarah \& Bentuk-bentuk Konstitusi Dunia, Bandung, Penerbit Nuansa dengan Penerbit Nusamedia.

Amsari, Feri. 2011. Perubahan UUD 1945, Perubahan Konstitusi Kesatuan Republik Indonesia Melalui Keputusan Mahkamah Konstitusi, Jakarta, Rajawali Pers.

Isjwara, F. 1966. Pengantar Ilmu Politik, Bandung, Penerbit Bina Cipta. 
Kelsen, Hans. 1961. General Theory of Law and State, Translated by Anders Wedberg, New York, Russel \& Russel.

Kelsen, Hans. 1992. Introduction to The Problems of Legal Theory, New York, Clarendon Paperbacks, Oxford University Press.

Nurtjahjo, Hendra. 2006. Filsafat Demokrasi, Jakarta, Bumi Aksara.

Juwana, Hikmahanto. 2001. Hukum Internasional dalam Konflik Kepentingan Ekonomi Negara Berkembang dan Negara Maju, Pidato Upacara Pengukuhan Sebagai Guru Besar Tetap dalam Ilmu Hukum Internasional pada Fakultas Hukum Universitas Indonesia, Depok.

Asshiddiqie, Jimly. 2005. Hukum Acara Pengujian UndangUndang, Jakarta: Sekretariat Jenderal dan Kepaniteraan Mahkamah Konstitusi.

Asshiddiqie, Jimly. 2005. Konstitusi \& Konstitusionalisme Indonesia, Jakarta: Konstitusi Press.

Starke, J.G. 2003. Pengantar Hukum Internasional (Edisi Kesepuluh), Jakarta, Sinar Grafika.

Wheare, K.C. 1975. Modern Constitutions, New York Toronto: Oxford University Press.

Fahmi, Khairul. 2011. Pemilihan Umum dan Kedaulatan Rakyat, Jakarta: Rajawali Pers.

Iver, R. M. Mac. 1980. Negara Modern, Jakarta: Aksara Baru.

Samidjo, 1986. Ilmu Negara, Bandung: CV. Armico.

Sekretariat Nasional ASEAN, 1992. ASEAN Selayang Pandang, Jakarta: Departemen Luar Negeri Republik Indonesia.

MD. Moh. Mahfud. 2011. Dasar \& Struktur Ketatanegaraan Indonesia (Edisi Revisi), Jakarta: Rineka Cipta.

Kusumaatmadja, Mochtar. 1976. Pengantar Hukum Internasional., Jakarta: Putra A Bardin. 
Yamin, Muhammad. 1952. Proklamasi dan Konstitusi Republik Indonesia, Djakarta: Djambatan.

Huda, Ni'matul. 2010. Ilmu Negara, Jakarta: Rajawali Pers.

Cumper, Peter. 1999. Cases and Materials-Constitution and Administrative Law, London: Published by Blackstone Press Limited.

Friedmann, W. 1953. Legal Theory (Third Edition), London: Stevens \& Sons Limited.

\section{B. Jurnal}

Ant, Andi Sandi.; \& Merdekawati, Agustina. 2012. Konsekuensi Pembatalan Undang-Undang Ratifikasi Terhadap Keterikatan Pemerintah Indonesia pada Perjanjian Internasional, Mimbar Hukum, Volume 24, Nomor 3, Oktober.

Falaakh, Muhammad Fajrul. 2002. Komisi Konstitusi dan Peran Rakyat dalam Perubahan UUD 1945, Jurnal Analisis CSIS Tahun XXXI/2002 No. 2, Penerbit Center for Strategic and Internasional Studies.

Aprilyawathi, Ni Ketut. 2015. Wewenang Mahkamah Konstitusi dalam Pengujian Undang-Undang Hasil Ratifikasi Perjanjian Internasional yang Bersifat Multilateral, Jurnal Yuridika: Volume 30 No. 1, Januari-April 2015.

\section{Peraturan Perundang-undangan dan Putusan Pengadilan}

Undang-Undang Dasar Negara Republik Indonesia Tahun 1945 The United States Constitution

Ketetapan MPR Nomor XX/MPRS/1966 tentang Memorandum DPR-GR Mengenai Sumber Tertib Hukum Republik Indonesia dan Tata Urusan Peraturan Perundangundangan Republik Indonesia.

Ketetapan MPR Nomor IV/MPR/1983 tentang Referendum Ketetapan MPR Nomor III/MPR/2000 tentang Sumber Hukum dan Tata Urutan Peraturan Perundang-undangan 
Vienna Convention on the Law of Treaties 1969 (Vienna Convention 1969).

Undang-Undang Nomor 24 Tahun 2000 tentang Perjanjian Internasional

Undang-Undang Nomor 38 Tahun 2008 Pengesahan Charter of The Association of Southeast Asian Nations (Piagam Perhimpunan Bangsa-Bangsa Asia Tenggara)

Charter of The Association of Southeast Asian Nations

Undang-Undang Nomor 12 Tahun 2011 tentang Pembentukan Peraturan Perundang-undangan

Putusan Mahkamah Konstitusi Nomor 008/PUU-II/2004 terkait Pengujian Undang-Undang Nomor 23 Tahun 2003 tentang Pemilihan Umum Presiden dan Wakil Presiden terhadap Undang-Undang Dasar Negara Republik Indonesia Tahun 1945

Putusan Mahkamah Konstitusi Nomor 33/PUU-IX/2011 terkait Pengujian Undang-Undang Nomor 38 Tahun 2008 tentang Pengesahan Charter of the Association of Southeast Asian Nations (Piagam Perhimpunan Bangsa-Bangsa Asia Tenggara)

\section{Website}

Taufik, Ade Irawan. Bola Panas Putusan Pengujian UndangUndang Pengesahan PiagamASEAN, http://www.rechtsvinding.bphn.go.idljurn al online/Bola $\% 20$ Panas $\% 20$ Putusan $\% 20$ Pengujian $\% 20$ UU\%0Asean $\% 20$ Charter \%20for\%20artikel\%20Kompas. pdf diakses tanggal 1 November 2014

Pengujian UU Ratifikasi Piagam ASEAN Kandas, http://www.hukumonline.com/berita/baca/l $\underline{\mathrm{t} 512 \mathrm{cb} 1408 \mathrm{c} 03 \mathrm{e} / \text { pengujian-uu-ratifikasi-piagam-asean- }}$ kandas, di akses tanggal 30 Oktober 2015.

Agusman, Damos Dumoli. Arti Penting ASEAN bagi Sistem Hukum Indonesia, http://www.antaranews.com/berita/360866/arti-piagamasean-bagi-sistem-hukum-indonesia, diakses tanggal 31 Oktober 2015. 